\title{
THE CONSTITUTION, TAXATION AND "AVOIDING PROLIXITY AND TAUTOLOGY"
}

\author{
KJ Keith*
}

Sir Kenneth Keith reviews the efforts made over the past 35 years to improve the drafting of New Zealand legislation in general and tax law in particular.

It is a pleasure to contribute to a festschrift for a long-valued colleague and friend. I do not claim any expertise in tax law, far from it. But perhaps something is to be gained from the view of an outsider, with experience in teaching, law reform and judging and arbitrating, all of them including some tax work.

The connections between the three parts of the article are both substantive and personal. In substantive terms, the first part of this article considers New Zealand's constitution, and in particular the Constitution Act 1986 and the Public Finance Act 1989, both of which continue Parliament's essential and historic role in respect of taxation and spending. The second part of the article looks more generally at the ways Parliament is to write the legislation, including laws imposing taxes. Part III considers how themes played out during the rewriting of the income tax legislation in the first part of this century. There is also a strong personal thread connecting the three parts of this article. During the 1980s, I was involved as an academic commentator and adviser with the constitutional legislation discussed in the first part of this article. During my time at the Law Commission, I engaged deeply with the themes covered in Part II of this article. I was also a member of the working group which initiated the rewriting of New Zealand's income tax legislation discussed in Part III.

\section{THE CONSTITUTION, TAXATION AND GOVERNMENT FINANCE}

The Treasury Report of 14 July 1984, Economic Management, released in the opening of the books exercise as a new Government was about to be formed, said that the New Zealand tax system was unsatisfactory in many respects. The newly elected Government, along with the many other challenges it faced, also had on its agenda major constitutional, foreign policy and economic reforms. An immediate problem it faced was the rapidly deteriorating situation of the New Zealand economy, exacerbated by the refusal of the outgoing Prime Minister to act on the advice of Treasury officials and the Reserve Bank and the strong views of the newly elected government-in-waiting on the need 
to devalue the New Zealand dollar. That problem was dealt with in the first instance by the immediate establishment of a constitutional convention that, when the outcome of the election was clear, the outgoing Government was to act on the advice of the incoming Government on matters of such great importance that the action cannot be delayed until the new Government formally takes office. ${ }^{1}$

A legal problem also appeared at that very difficult time (with a southerly storm raging in Wellington and a meeting of the ANZUS treaty partners scheduled by the outgoing Prime Minister for the days after the election): under the law; were the potential Ministers still members of Parliament and accordingly able to take office as Ministers ${ }^{2}$ That matter was resolved by the enactment in 1986 of the Constitution Act. ${ }^{3}$ That Act also repealed the remnants of the New Zealand Constitution Act enacted as long ago as 1852 by the Imperial Parliament, a statute which provided for representative government, originally at both the general and provincial levels, and which was very soon seen, by way of constitutional convention, as providing for responsible government.

In the 1986 Act, Parliament took the opportunity to restate basic propositions about its role in relation to finance established as long ago as 1627 and 1689 in the Petition of Right and the Bill of Rights. It was, Parliament declared, unlawful for the Crown to tax, borrow and spend except by or under an Act of Parliament. ${ }^{4}$ The first matter is, in part, dealt with by the income tax legislation, which I consider in a limited way in the last part of this article, and by annual taxing statutes.

The Public Finance Act 1989, like its predecessors of 1977 and 1953, repeats that borrowing cannot occur without the approval by a statute. ${ }^{5}$ But the very next section empowers the responsible Minister, on behalf of the Crown, to raise a loan from any person, organisation or government within or outside New Zealand upon such terms and conditions as they think fit, if it appears to them to be necessary or expedient in the public interest to do so. ${ }^{6}$ As a matter of law, the power is the Minister's

* Professor Emeritus, Te Kauhanganui Tātai Ture, Te Herenga Waka | Faculty of Law, Victoria University of Wellington. Thanks to Ross Carter (especially for his corrections) and Jonathan Stuart for comments on the draft, and to those named and unnamed in this article who have helped to improve my understanding of the better drafting of legislation and other documents over many decades.

1 See Cabinet Office Cabinet Manual 2017 at [6.29].

2 See KJ Keith "Constitutional Development - An Introduction" (1985) 15 VUWLR 5: the articles referred to there and the reports leading to the new Constitution Act, Department of Justice, Constitutional Reform, Reports of an Officials Committee (1985). For commentaries on the devaluation crisis see Hugh Templeton All Honourable Men: Inside the Muldoon Cabinet 1975-1984 (Auckland University Press, Auckland, 1995) at 221; and Barry Gustafson His Way: A biography of Robert Muldoon (Auckland University Press, Auckland, 2000) at chapter 22.

3 Section 6(2)(a)

4 Section 22

5 Section 46

6 Section 47; and see also ss 48-65ZH. 
alone; Cabinet consideration, leading, say, to an Order in Council, is not required. Practice, no doubt, does often require that. The Controller and Auditor-General also has a role. ${ }^{7}$ Neither does Parliament have a role in respect of the repayment of loans. Rather, the 1989 Act grants permanent legislative authority and indeed requires repayment. ${ }^{8}$ Such payments do, however, appear in the Estimates. ${ }^{9}$ The Government is subject to the discipline of the measure enacted in 1994 as the Fiscal Responsibility Act which was later incorporated into the Public Finance Act 1989 as Part 2. ${ }^{10}$

The Public Finance Act, in accordance with the requirement in the Constitution Act for legislative approval of spending, elaborates on the Fiscal Responsibility Act in provisions designed to enhance the powers of the House to scrutinise Government spending, a matter which has also been considered by the New Zealand Court of Appeal. ${ }^{11}$

The Constitution Act repeated in its s 21 the substance of the requirement of s 54 of the 1852 Act that any Bill involving an appropriation or imposing a charge on the Crown was not to be enacted unless the Crown had recommended the measure. That provision reflected the principle that the Government in office, with the support of the House of Representatives, should not have spending requirements imposed on them. That statutory requirement was supported by Standing Orders of the House, but their capricious application by different Speakers and Chairpersons led to changes. ${ }^{12}$ In 1995 the Standing Orders Committee proposed changes aimed at reconciling the principle that the Government of the day is responsible for the Crown's financial position and had to have control over its fiscal aggregates with the desire of members to promote policies that involved some expenditure. The House adopted the changes the following year. The means they introduced was the Government financial veto. A minister can invoke the veto if they assess that a measure will have more than a minor impact on the fiscal aggregates were it to become law. The Minister's assessment cannot be questioned and if the veto remains as the measure passes through the House the measure cannot be the subject of a vote at the third reading. ${ }^{13}$ That procedure may be seen as anti-democratic but it does

7 See for example Mary Harris and David Wilson (eds) McGee Parliamentary Practice in New Zealand (4th ed, Oratia Books, 2017) at 513.

8 Section $65 \mathrm{ZH}$.

9 Public Finance Act 1989, s 14.

10 For an earlier discussion see ML Longdin-Prisk "Setting Legal Limits to Government Borrowing" (1986) 12 NZULR 160.

11 Harris and Wilson, above $\mathrm{n} 7$, at 536-542; and Archives and Records Association of New Zealand v Blakeley [2000] 1 NZLR 607 (CA) at [58]-[82].

12 Harris and Wilson, above $\mathrm{n} 7$, at 515 .

13 See Standing Orders Committee "Review of Standing Orders" [1993-1996] AJHR I.18A at 61-65; and Standing Orders Committee "Review of Standing Orders" [1993-1996] AJHR I.18B at 4 and 67. 
allow for a fuller debate on the merits of a measure and the veto has been rarely invoked. ${ }^{14}$ It is a matter of concern, at least to me, that it was not for another nine years that the related section in the Constitution Act was repealed, and then by way of a Statutes Amendment Bill. What does that delay about a core constitutional statute say about our commitment to constitutional values? ${ }^{15}$

\section{THE TANNER TRIPOD}

Considerable progress has been made on all those matters down the years, particularly under the influence of George Tanner QC, one-time Chief Parliamentary Counsel and Law Commissioner. Tanner liked to refer to three matters as essential to a better statute book: ${ }^{16}$

- a new interpretation statute;

- a new format; and

- $\quad$ structure and style.

Considerable progress has been made throughout the years, especially under his wise tutelage, but more undoubtedly continues to be required. ${ }^{17}$ The Act establishing the Law Commission, of which I was an original member and later President, gave important responsibilities in respect of such matters to the Law Commission: to advise Ministers on ways in which the law of New Zealand can be made as understandable and accessible as possible and, in making recommendations, to have regard to the desirability of simplifying the expression and content of the law, again, as far as that is practicable. ${ }^{18}$ Those instructions may be related back to the instructions given by Queen Victoria on 5 December 1840 to her trusty and well-beloved William Hobson, Her Governor and Commander-in-Chief in and over New Zealand, that all laws and ordinances which he was to enact with the advice and consent of the new Legislative Council were to "be drawn in a simple and compendious form, avoiding as far as may be all prolixity and tautology". The Supreme Court Ordinance 1841, drafted during a lengthy sea

14 Harris and Wilson, above n 7, at 515-520. I am grateful to Tyrone-Jay Barugh for an LLM Research paper on the financial veto: Tyrone-Jay Barugh "The Power to Propose: An Analysis of the Government's Financial Veto" (LLM Research Paper, Te Herenga Waka | Victoria University of Wellington, 2017).

15 See more broadly about the constitution and tax Lindsay McKay "Taxation and the constitution" (1985) 15 VUWLR 53.

16 George Tanner "Confronting the Process of Statute-making" in Rick Bigwood (ed) The Statute: Making and Meaning (LexisNexis, Wellington, 2004) 49 at 66-74. For a recent excellent overall account see Ross Carter Burrows and Carter Statute Law in New Zealand (5th ed, LexisNexis, Wellington, 2015) at chapters 4 and 5; and Ross Carter "Interpretation Acts - Are they, and (How) Do They Make for, Great Law?" [2020](3) The Loophole 2 at 52. For earlier changes see TY Chan "Changes in Form of New Zealand Statutes" (1975) 8 VUWLR 318.

17 See the Law Commission Report, prepared in conjunction with the PCO, Law Commission Presentation of New Zealand Statute Law (NZLC R104, 2008), implemented in part by the Legislation Act 2012; and see in particular Parliamentary Counsel Office "PCO Plain Language Standard" <www.pco.govt.nz>.

18 Law Commission Act 1985, s 5(1)(d) and (2)(b). See also the Legislation Act 2019, s 129. 
voyage by the first Chief Justice and the Second Attorney-General, provides an early striking example, even if it was disallowed by the authorities in London. In just five provisions extending over 15 lines it established the Court and conferred jurisdiction on it in capacious terms, avoiding, for instance, the divide which has bedevilled the law of New South Wales between Common Law and Equity. ${ }^{19}$

In its first Report, the Commission took an early step to meet those responsibilities by reviewing a Bill which was already before Parliament, stating the Imperial law which was thought still to be part of the law of New Zealand. That Report aimed to do two things: to assist in validating the list of Imperial legislation that was still in force, which was to appear in Schedules to the Act, and to prepare clearer and more accessible substantive provisions. ${ }^{20}$

The first involved a careful check, assisted by experts particularly on ancient property law statutes, of the legislation which was considered still to be part of New Zealand law and which should remain so. The Report also made that legislation accessible by setting it out in full for the first time since the late 19 th century.

The second appears from the two pages of the substantive provisions in the Commission's text, compared with the 20 pages in the Bill prepared by the Parliamentary Counsel Office. The Commission's draft also excluded provisions which it considered were not needed. One concerned the English Laws Act 1908, and in particular, its reference to the common law of England continuing to be part of the law of New Zealand. Given that the legal profession, including the judges, had long used that body of law as a matter of course, such a provision could serve no possible purpose. But Parliament in 1988 in the Imperial Laws Act (reduced to four pages, apart from the Schedule) did not follow that recommendation and included a provision to the effect that the common law of England, to the extent that it was part of the law of New Zealand at the commencement of the Act, would continue to be part of the law. The Courts, to the extent that they have considered it, have, of course, never taken seriously its apparent temporal and geographic limits. ${ }^{21}$

There followed reports on Legislation and its Interpretation: Statutory Publications Bill, ${ }^{22}$ A New Interpretation Act: To Avoid "Prolixity and Tautology"23 and The Format of Legislation. ${ }^{24}$ As George

19 See also GA Wood "Construction and Reform: The establishment of the New Zealand Supreme Court" (1975) 5 VUWLR 1; and PA Cornford "The Administration of Justice in New Zealand 1841/1846 (a legislative chronicle) [Part II]: The Swainson Period" (1970) 4 NZULR 120 at 124-126.

20 Law Commission Imperial Legislation in Force in New Zealand (NZLC R1, 1987).

21 See Chamberlains v Lai [2007] 2 NZLR 7 at [87] and [125]; and Law Commission Presentation of New Zealand Statute Law, above n 17, at [15]-[16].

22 Law Commission Legislation and its Interpretation: Statutory Publications Bill (NZLC R11, 1989).

23 Law Commission A New Interpretation Act: To Avoid "Prolixity and Tautology" (NZLC R17, 1990).

24 Law Commission The Format of Legislation (NZLC R27, 1993). 
Tanner has correctly and generously recognised, Dr William Sewell, a senior researcher at the Commission, made major contributions to that work. He was an outstanding editor, writer, reviewer, German scholar, linguist, poet and lawyer. ${ }^{25}$ It is hardly possible to measure the overall positive impact of these efforts but, as mentioned later, some specific calculations are available.

The Commission's letter to the Minister of Justice, recommending the adoption of the new format proposed by the 1993 Report, mentioned the work which was well-advanced on a legislation manual for New Zealand, a manual which would build on the Report of the Legislation Advisory Committee, Legislative Change: Guidelines on Process and Content. ${ }^{26}$ Those Guidelines have been endorsed by Cabinet as the key point of reference for assessing whether draft legislation conforms to accepted constitutional and legal principles. ${ }^{27}$ The letter also referred to the recently tabled Second Report of the Working Party on the Reorganisation of the Income Tax Act 1976, a report considered in the last part of this article. The report on a legislation manual was published in 1996 and has been largely adopted in practice by the Parliamentary Counsel Office. I think I can say that those changes and the very large savings arising from them have largely gone unnoticed.

Much of the work on those reports was helped by the extensive work on better drafted and presented legislation and, more generally, legal documents, particularly by those engaged in the plain language movement. The Victorian Law Reform Commission, led by Professor David Kelly, was a major early contributor, particularly in its 1987 Report, Plain English and the Law. ${ }^{28}$ That Report, in its four volumes, demonstrated the changes the Commission was recommending by including new versions of the Takeovers Code and various other legal documents.

The efforts were not only at the governmental level; Notably, the organisation Clarity, which published a valuable journal under that name, with sterling support from many, especially Professor Joseph Kimble, an American Law Professor, and Robert Eagleson, an Australian Professor of English. ${ }^{29}$

25 Harris and Wilson, above $\mathrm{n} 7$, at 67

26 Legislation Advisory Committee Legislative Change: Guidelines on Process and Content (rev ed, 1991).

27 See now Cabinet Office Cabinet Manual 2017 at [7.38]

28 Victorian Law Reform Commission Plain English and the Law (VLC R9, 1987).

29 See for example Joseph Kimble "Plain English: A Charter for Clear Writing" (1992) 9 T M Cooley L Rev 1; and Robert Eagleson "Ensnaring perceptions on communication: Underlying obstacles to lawyers' writing plainly" (2009) 62 Clarity 9. 


\section{INCOME TAX ACT 1994: AVOIDING PROLIXITY AND TAUTOLOGY? ${ }^{30}$}

In November 1992 the Government established a working group chaired by Arthur Valabh and including Margaret Bazley, a senior public servant and me, to advise on the reorganisation of the Income Tax Act 1976. Valabh was an experienced Auckland accountant who had previously chaired the Consultative Committee on the Taxation of Income from Capital. Among other things, the Consultative Committee had recommended that the Income Tax Act 1976 and the Inland Revenue Department Act 1974 be reorganised. Our working group reported in August 1993. Our report spanned three volumes, including draft legislation extending over 2000 pages. ${ }^{31} \mathrm{I}$ emphasise that the contributions to the work of the Group extended far beyond that of the three of us. In our letter to the Ministers of Finance and Revenue which proposed that the draft statutes we had prepared be introduced into Parliament, we recorded our thanks to: Garth Thornton QC, a very talented and experienced law drafter and our legal counsel; to Don LeQuesne, on the technical aspects of tax law; Sir Ivor Richardson; six leading tax practitioners; IRD officials; and in particular Brent Lewers, and Daphne Brassell (who also provided valuable services to the Law Commission) for her skilful editing. Having Garth Thornton so closely involved provided support for the view of continental critics about the divide between policymakers and drafters to be found in many parts of the Anglo-Saxon world should not the thinkers, they ask, also be doing the writing? I had already been part of such integrated processes in the Danks Committee on Official Information, in preparing the draft Bill of Rights, at the Law Commission and when working in international negotiations.

In preparing for the work on the 1976 Act, I went to the two large heavy brown authoritative volumes of the Income Tax Act 1976 as reprinted by the Government Printer in 1993. At an early meeting, the experts I have just mentioned looked at me lugging those volumes with some amusement. They all had the much more convenient commercially published versions of the legislation, copies of which I later used and saw being used in court when I sat as a judge in tax cases, no issue ever being raised about their lacking of authority because of the absence of the Government Printing Office imprimatur.

That reprint began with Part I, headed "Interpretation", the 10 sections of which extended for 100 pages. The next two parts concerned the making of return by the taxpayer, assessment by the IRD and objections to assessments. It was only after 143 pages, in Part IV, that the heading "Income Tax" first appeared. Its first section defined "absentee", a status which excludes liability to pay tax. It was only in the next section that Parliament required those receiving income to pay tax on it, although in a

30 Compare our honorand's inaugural lecture, John Prebble "Why is Tax Law Incomprehensible?" [1994] BTR 380

31 [1993] AJHR B31. 
sentence which began with the off-putting words "Subject to the provisions of this Act...". Plainly the order of the statute and some of its wording had to be changed.

That need was also demonstrated by some of the extraordinary numbering in the statute, resulting from new sets of provisions being squeezed into it. After s 393 (s 394 having been repealed), appeared 140 pages of ss 394 A to ss 397 , too many to count.

The two official volumes presented further challenges. The pages did not have running heads indicating the name of the statute, the part, the section or the subsection. The commercial versions, by contrast, did have running heads. And some of the sections were very long: s 245GA, for instance, with 15 subsections ran to 10 pages. Many sentences too were very long. Section 68, providing for the taxing of retirement allowances, exempted in its subs (5) certain allowances. That subsection had more than 150 words.

With excellent advice, we very quickly realised that new approaches were called for. One early decision was to put the definitions at the back of the statute. Think, someone said, about the glossary in or the index to a book. They are found at the back, not cluttering the front. Somewhat similarly, the administrative provisions of Parts III and IV were hived off into proposed Tax Administration and Taxation Review Authorities Acts. The obligation to pay tax on income was about to move from page 143 to page two in the first substantive provision of the Act, with the second requiring an annual taxing statute.

The major organisational proposal was to present the law in a reorganised form within a soundly based and coherent structure of Parts and Subparts. This purpose is reflected in the purpose and interpretation section of the Income Tax Act 1994, which was the immediate result of that work. ${ }^{32}$ The numbering of that provision hints at another significant change: the use of an alphanumeric system for organising the statute. That was designed to enable the slotting in of new provisions within the carefully reorganised statute. The Prime Minister of the day reported, as he convened a major meeting to approve the direction of the proposed measure, that the people of the King Country (where he had been campaigning) were speaking of nothing else but the alphanumerical organisation of the Income Tax Act!

32 Income Tax Act 1994, s AA 1 provided that:

The main purposes of this Act are (a) to impose tax on income; (b) to impose obligations in respect of tax; (c) to set out rules to be used to calculate the tax and to satisfy the obligations imposed ...

Section AA 3(1) provided as a principle of interpretation that:

The meaning of a provision of this Act is found by reading the words in context and, particularly, in light of the purpose provisions, the core provisions and the way this Act is organised (emphasis added). 
The Minister of Revenue, in moving that the Working Group's Report and the draft Bills be referred to the Finance and Expenditure Committee on the last day of the 1990-1993 Parliament, said that the 1976 Act placed needlessly high costs on the business sector and that the Government sought as a matter of policy to keep compliance costs down. ${ }^{33} \mathrm{He}$ and the Finance Minister had received a delegation of leading tax professionals strongly supporting the proposals made in the Report and the New Zealand Society Council of Accountants had also expressed strong approval for the proposed repackaging. ${ }^{34}$

Part A of the new Act, headed "Purpose and Application", was followed by Part B "Core Provisions", Part C "Income further defined", Part D "Deductions further defined", and so on to Part $\mathrm{O}$, headed "Definitions and related matters" (Both income and deductions had been partly, but not fully, addressed in the Core provisions). The Core provisions, as prepared by the Working Group, consisted of 14 sections, all within five pages. ${ }^{35}$ The sentences were also much shorter than those in the 1976 Act and the format presented the proposed legislation much more clearly. The Act was careful to say, as had the Minister in submitting the Report to Parliament, that its reorganisation and the changes to the style and language were not to affect the interpretation or effect of those provisions.

Other changes recommended by the Working Group and adopted in the 1994 statute included:

- $\quad$ removing or replacing archaic or unnecessary words or phrases; ${ }^{36}$

- referring to defined words and terms at the end of each section in which they occur;

- drafting shorter sections and sentences;

- $\quad$ using the present tense (except of course where a future event is being addressed);

- not nominalising verbs; ${ }^{37}$

- using the active rather than passive voice;

- $\quad$ using "must" rather than "shall" to indicate an obligation;

- $\quad$ using gender-neutral language;

- $\quad$ using flow charts, diagrams, algebraic formulas and examples.

33 David Kelly in a seminar organised by the Law Commission in 1988 at the beginning of its work on the drafting and presentation of legislation gave some British and Victorian figures showing the savings in money and time from better legislation and forms: see Law Commission Legislation and its Interpretation: Discussion and seminar papers (NZLC PP8, 1988) at 58-59, referring to the Victorian report Victorian Law Reform Commission Plain English and the Law, above n 28, at [100]-[107].

34 (23 September 1993) 538 NZPD 18362-18363.

35 Above n 23, at 89-93.

36 Such as "hereby", "hereinafter", "hereinbefore", "therein", "thereto", "thereof", "pursuant to", "from time to time", "of this Act", "of this section", and replacing formulations such as "31st day of March" with the simpler "31 March".

37 For instance, "apply" rather than "make application". 
Many of these changes were appearing in legislation in New Zealand and abroad; the ideas are, of course, not new. The Law Commission's Report on a new Interpretation Act refers to a rule of court made by Francis Bacon as Chancellor: if a pleading "shall be found of immoderate length both the parties and the counsel under whose hand it passeth shall be fined". 38

The 1994 Act was only ever seen as a starting point, although an essential one, in a process. Sir Ivor Richardson, who chaired the Rewrite Advisory Panel from 2003 to 2008 and therefore had a major hand in the Income Tax Acts of 2004 and 2007 (the current one) has valuably described that process. He has emphasised the critical importance of the process being collaborative, subject to challenge as it proceeded and bipartisan. ${ }^{39} \mathrm{I}$ limit myself to comments on a limited range of matters. By the time those changes were occurring I had changed hats, with my very first case as a judge being about income tax! ${ }^{40}$

A 1996 amendment made two relevant changes, one of style, the other concerning interpretation. The headings to the sections were raised above the text of the provision, again part of the reformatting of the statute book. Section AA3 provided that the meaning of a provision of the Act:

is found by reading the words in context and, particularly, in light of the purpose provisions [which had been spelt out in a different form], the core provisions and the way in which the Act is organized.

That provision is of interest for several reasons, first for its emphasis on "reading" the provision in question. It was said of Felix Frankfurter, when he was a professor, that he had three rules of statutory interpretation: read the statute, read the statute, read the statute! Second, what is the need for such a direction given the terms of s 5(j) of the Acts Interpretation Act 1924 looking to a purposive interpretation? Perhaps the influence of the Law Commission report on a new Interpretation Act submitted in December 1990 was to be seen; its proposed s 9(1) would have provided that the meaning of an enactment is to be ascertained from its text in the light of its purpose and in its context. Third, we may also see the influence of Sir Ivor Richardson who often in his judgments and extrajudicial writing emphasised the scheme and purpose of legislation and in particular tax legislation. John Prebble has commented on the difficulties he saw in that provision. ${ }^{41}$

The Income Tax Act 2004 contains no general interpretation provision, a recognition, I take it, of the direction then to be found in s 5 of the Interpretation Act 1999. This is a provision which, contrary

38 Law Commission Legislation and its Interpretation: Statutory Publications Bill, above n 22, at [12].

39 Ivor Richardson "Simplicity in Legislative Drafting and Rewriting Tax Legislation" (2012) 43 VUWLR 517.

40 Egmont Co-operative Dairies Ltd (In Liquidation) v Commissioner of Inland Revenue [1996] 2 NZLR 419, a case which turned more on the interpretation of the insurance contract under which the Co-operative had received the payment in issue than on the 1976 Act.

41 John Prebble "The Interpretation Provisions in the New Zealand Income Tax Act 1994" (1999) 30 VUWLR 49; and for a related comment see JF Burrows "The Interpretation Act 1999" in Rick Bigwood (ed) The Statute: Making and Meaning (LexisNexis, Wellington, 2004) 211 at 212. 
to the Law Commission's proposal, did not include the reference to "context", an exclusion which in practice has had no consequence. Parliament has since recognised that reality by including "in context" in s 10 of the Legislation Act 2019. ${ }^{42}$

The 2007 Income Tax Act still has the same basic features as that of 1994, along with improvements, particularly in style and format, some introduced across the statute book a few years earlier. The enacting provision is in the active sense: "The Parliament of New Zealand enacts ..." rather than as a subjunctive passive: "Be it enacted by the Parliament ...". The headings to sections are raised. Definitions do not have quote marks around them; rather, they are in bold and begin with a lower case letter. Subparagraphs within a provision do not begin with a capital. There is more white around the text. The typeface is now Times New Roman rather than Baskerville. The result is that the statutory page is much easier to read.

On substance, I mention just one curiosity introduced in the 2007 Act. Section AA 4 provides that the Crown is bound by the Act. That is the first time that such a provision has been included in an Income Tax Act. Has not the basic principle been clear since the 17th century? No one has earlier seen the need to state the obvious. Is this not yet another piece of evidence that the proposal the Law Commission made 30 years ago to reverse the statutory presumption that the Crown is not affected by legislation unless it expressly says so be revisited and put on the statute book? It would reduce by a line or two very many statutes, hardly a major contributor to the "avoidance of prolixity and tautology", but a small step in that direction; a step in accordance with principle and practicality as the Commission demonstrated. ${ }^{43}$

Better drafting cannot, of course, always provide clear answers to all questions. Consider the distinction, critical in income tax law, between capital and income, as it played out in disputes which were resolved by courts relating to Laurence Olivier, Ray Henwood and Ian Fraser, favourably to them with the payments in question being ruled as capital and not income. ${ }^{44} \mathrm{~A}$ similar challenge was presented by the distinction between property and income under matrimonial property legislation. ${ }^{45}$ Do tax changes fall within the protections accorded to foreign investors by bilateral investment

42 See also Ross Carter "New interpretation legislation - changes to Interpretation Act 1999" [2019] NZLJ 409.

43 Law Commission A New Interpretation Act: To Avoid "Prolixity and Tautology", above n 23, chapter IV; and Steven Price "Crown immunity on trial - the desirability and practicability of enforcing statute law against the Crown" (1990) 20 VUWLR 213.

44 Higgs v Olivier [1952] 1 Ch 311 (CA); Henwood v Commissioner of Inland Revenue (1995) 17 NZTC 12,271, (1995) 19 TRNZ 869 (CA); and Commissioner of Inland Revenue v Fraser (1996) 17 NZTC 12,607 (CA).

$45 Z$ Z Z [1997] 2 NZLR 258 (CA). 
treaties? Or consider the challenges, which our honorand has frequently addressed, presented by the drafting and application of a general anti-avoidance provision. ${ }^{46}$

\section{CONCLUSION}

I conclude with a question for the law schools, thinking of the places where our honorand has spent most of his professional life. Do they give sufficient attention to the drafting of legal documents? The question is not limited to legislation. ${ }^{47}$ Consider, as well, contracts of many different types (conveyances, mortgages, loan agreements, company documents, insurance policies ...); legal opinions; submissions to Parliamentary committees, to inquiries, to courts; directions to the jury and, a matter addressed in New Zealand in seminars as judgment writing; judgments; and the preparation of constitutions and treaties. ${ }^{48}$

Has the extensive body of writing about plain language and the law faded into the past? Or the wise advice of George Orwell ${ }^{49}$ and Albert Einstein alike: make things as simple as possible, but not simpler?

46 See for example John Prebble "Criminal Law, Tax Evasion, Shams, and Tax Avoidance: Part 1 - Tax Evasion and General Doctrines of Criminal Law" (1996) 2 NZJTLP 3; John Prebble "Criminal Law, Tax Evasion, Shams, and Tax Avoidance: Part II - Criminal Law Consequences of Categories of Evasion and Avoidance" (1996) 2 NZJTLP 59; and Zoë Prebble and John Prebble "The Morality of Tax Avoidance" (2010) 43 Creighton LR 693.

47 See John Burrows "Legislation as a Degree Course" in Claudia Geiringer and Dean Knight (eds) Seeing the World Whole: Essays in Honour of Sir Kenneth Keith (Victoria University Press, Wellington, 2008) 151; and Andrew Burrows Thinking About Statutes: Interpretation, Interaction, Improvement (Cambridge University Press, Cambridge, 2018), an academic turned United Kingdom Supreme Court Justice, whose first concluding observation is that "we need to spend far more time in our university law schools researching, and teaching in an engaging and practical way, about statute law as a coherent whole": at 128.

48 See (2004) 52 Clarity Journal: its section headed "Progress in New Zealand" has articles on legislation generally, the Income Tax Act 2004, judgment writing, preparing a constitution for an incorporated society and writing for law graduates.

49 George Orwell "Politics and the English Language" (1946) 13 Horizon: A Review of Literature and Art 252. 